\title{
Evolution from Darwin to DNA on Show in Brazil
}

\author{
Mick Wycoff
}

Published online: 19 June 2008

(C) Springer Science + Business Media, LLC 2008

Thanks to the work of its famous modernist architects, Brazil may have more than its share of famous museum buildings; but until last year, the history of science exhibitions was close to nil. So, the resoundingly enthusiastic response to Darwin in Saõ Paulo last May came as a surprise. The show, originating in 2005 at the American Museum of Natural History in New York City (AMNH), ran for just 10 weeks at Museu de Arte de São Paulo (MASP), where it drew crowds surpassed only by longerrunning shows in past years devoted to Picasso and Michelangelo. Translated into Portuguese and retooled with specific reference to Darwin's visit to Brazil early in the voyage of the Beagle, the exhibition recently closed in Rio de Janiero and travels next to the capital city of Brasilia. Future venues will cover most of the important cities in Brazil, including Belo Horizonte and Porto Alegre.

"Darwin was the first scientific exhibition of that size and quality that was ever done in the 500-year history of Brazil," reports Ben Sangari, whose educational Instituto Sangari is responsible for bringing both Darwin and the Genomics Revolution to Brazil (see preceding article). The public response - over 200,000 visitors to MASP - proves to Sangari that people of all backgrounds are interested in science. And if Darwin was not enough, Sangari proved his point again at yet another iconic Saõ Paulo museum when he and his team of designers and researchers opened the Genomic Revolution (A Revolução Genômica) on February 29, 2008 in the Pavilion Armando de Arruda Pereira

M. Wycoff $(\bowtie)$

433 East Saddle River Road,

Ridgewood, NJ 07450, USA

e-mail: meldredge@earthlink.net located in the popular Saõ Paulo Ibirapuera Park. The iconic building is a concrete showplace designed by Oscar Niemayer, happily treated to a badly needed facelift for the Genomic Revolution. The show remains open until July 13 before traveling to other museums in Brazil. Attendance in Saõ Paulo is predicted to top 500,000.

Anyone familiar with these two outstanding exhibitions from their first run at the AMNH or subsequent appearances in the US and Toronto will recognize the substance of each now, but important additions enhance both shows for Brazilian audiences. Genomics retains all its fun and informative interactives while cutting down on the lengthy English text and adding a living biodiversity segment. Darwin keeps the detailed historical perspective that offers an overview of the great naturalist's life while it zeroes in on the Beagle trip for evidence of the three major clues that brought him to evolution: (1) replacement of extinct organisms by modern representatives, as seen in examples of fossil and living armadillos (Fig. 1); (2) replacement of species by relatives that Darwin saw while he traveled south down the continent, as in the example of the greater and lesser rheas (Fig. 2); and (3) especially the difference between closely related species on islands in the Galapagos and other archipelagos, for example in mockingbirds and tortoises (Fig. 3).

What is new in Sangari's version of Darwin jumps out at once: the powerful impact Brazil's tropical landscape had on a young Englishman who had long dreamed of seeing the rainforest first-hand. Darwin's famous quote, "The mind is a chaos of delight," (Fig. 4) conveys the lad's wide-eyed response to his first glimpses of the then-intact Atlantic rainforests of Bahia, the Beagle's first landfall in Brazil. This Portuguese language version of the exhibition includes an enlarged 19th Century engraving of the kind of jungle setting Darwin would have seen, comments about his 
Fig. 1 Saõ Paulo students stop to consider some implications of Darwin's ideas about evolution. Credit: Hill \& Knowlton

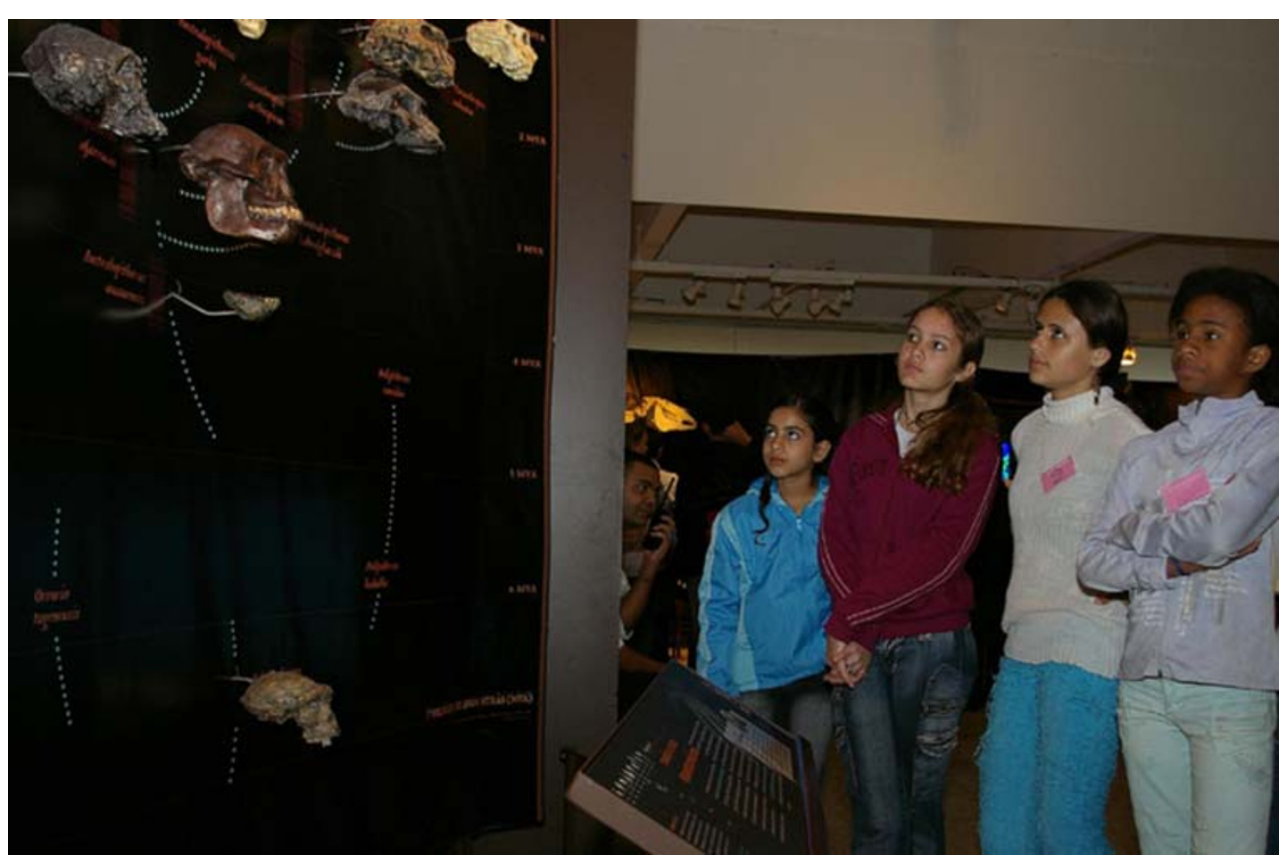

reaction to the colonial Portuguese (rather critical), and an enlarged series of captivating sketches by ship's artist Conrad Martens of scenes from the interior with lanky gauchos astride their bony mounts, reminding us that Darwin himself spent much of his South American journey on horseback exploring on land. But the most powerful addition is more social than scientific. There is a rivetingif somewhat disturbing-brief slide show illustrating the practice of slavery in Brazil during the 1830's when Darwin visited. More pictures and quotes from Darwin tell the story of his angry scorn for a plantation owner's insistence that his slaves were happy in their captivity.
In preparing a Portuguese language version of Genomics, the exhibitors were faced with text already too long and too complex for their target demographic - high school students. A direct translation would have made the reading some $30 \%$ longer. The solution was to pare down the text and expand the show. Since Brazil is biodiversity incarnate, and since its many urban kids know little of the living riches of their homeland, why not show them a sliver of their native wilds to mirror the wonders DNA has wrought? More walk-in terrarium than zoo, the rainforest exhibit is laid along the museum's high glass wall of windows overlooking the public park outside. A

Fig. 2 The triple helix structure of DNA stands as a dominating image of the Genomic Revolution exhibition. Credit: Hill \& Knowlton

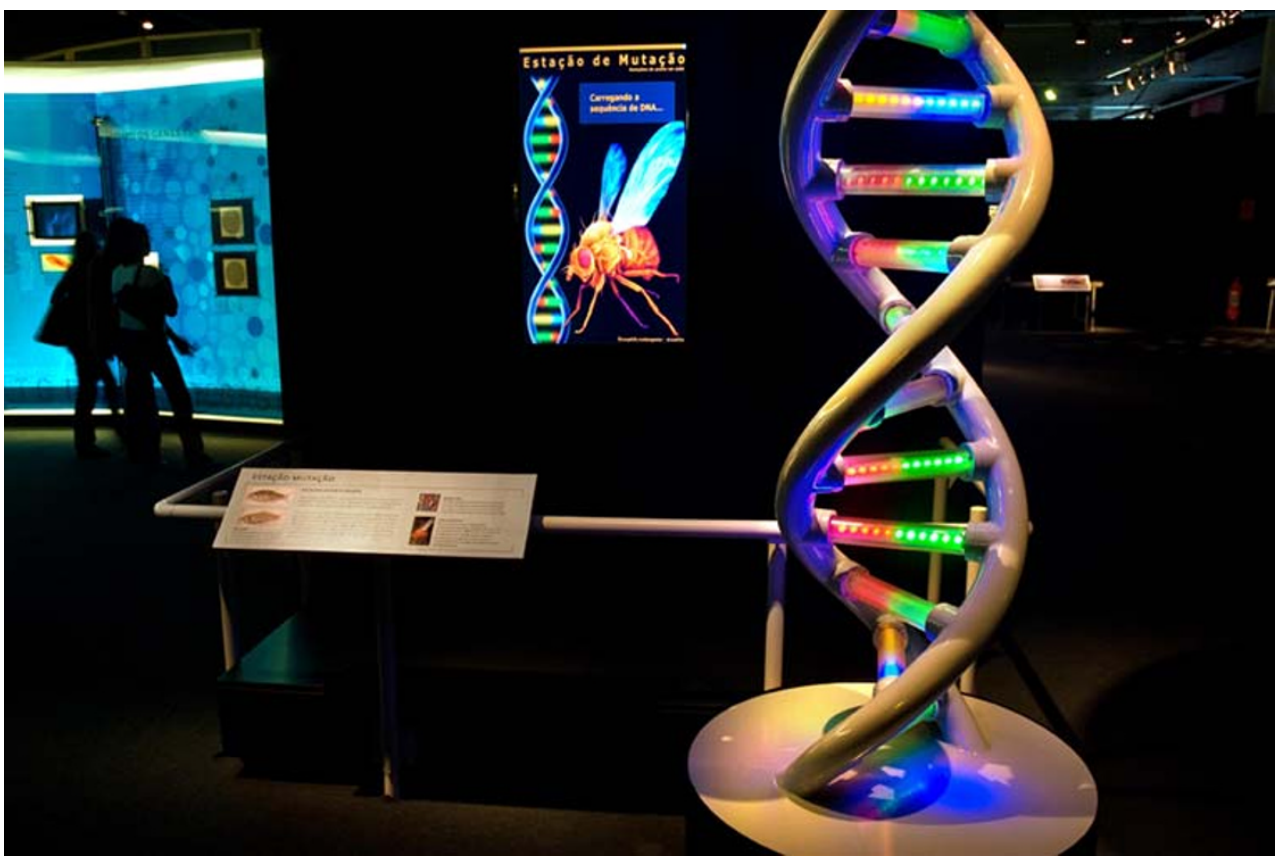




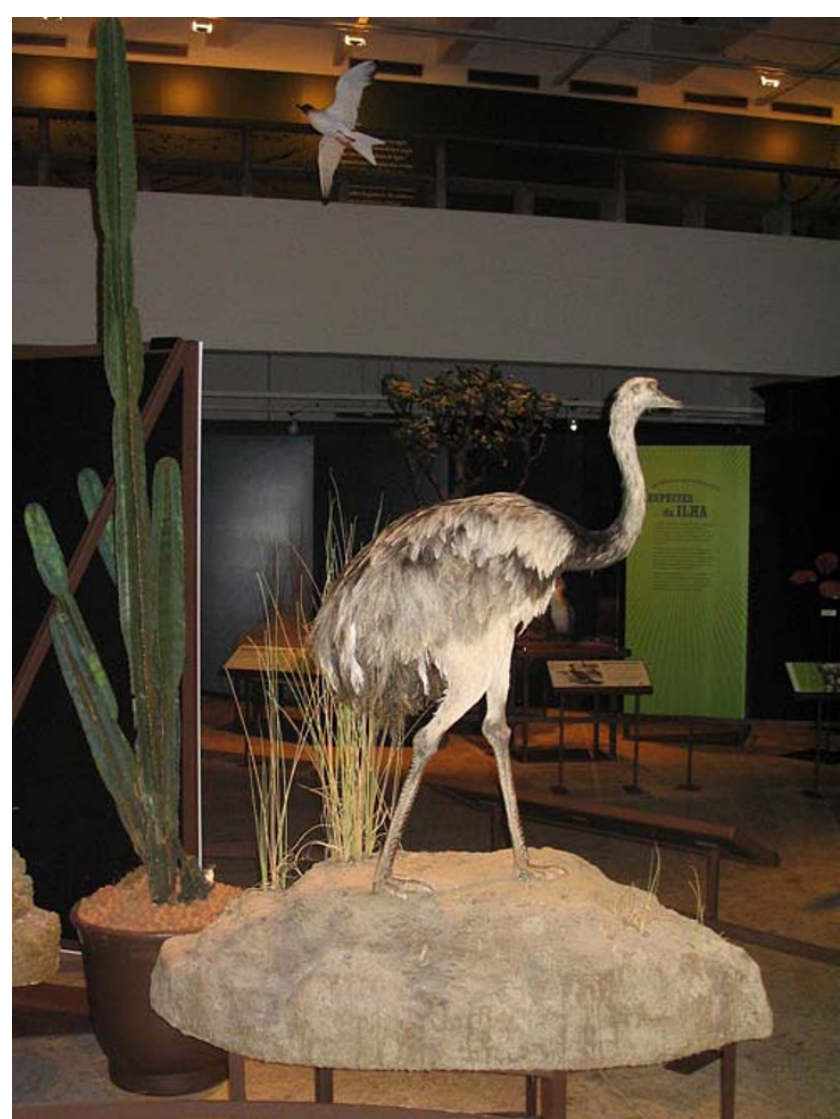

Fig. 3 As Darwin traveled south in Brazil, he found the greater rhea replaced by the smaller but closely related lesser Rhea. Credit: Alan Draeger, AMNH wide wood-planked gangway traverses a landscape of native tropical trees, shrubs, vines, and flowering plants. Roomy glass cases display a wide array of native species including bright toco toucans (Fig. 5), a young native alligator called jacaré (Fig. 6), an aquarium full of Amazonian fish, another of swimming turtles (Fig. 7), and a green iguana.

From this world of light and active life, the visitor moves into a darkened room lined with lit-up glass cases filled with glassy eyed taxidermied specimens of birds, monkeys, and other small mammals and a fierce-looking jaguarmost of them endangered or nearly extinct (Fig. 8). It is the hard part of the lesson of why we should care about conserving biodiversity (Fig. 9).

The transition from the macrocosm into the microcosm of DNA is cleverly finessed with a passage through a roomsized model of a cell complete with organelles where the DNA is housed (Figs. 10, 11, 12). Visitors exit into a large, dark, and coolly lit space filled with glowing pillars of light, here an enormous model of a fly that can be visibly made to mutate by playing with an interactive panel; there, a flat-screen video game that lets you find how much genetic code you share with a banana (25\%!). Backlit panels highlight the great mixture of human gene pools that makes up the Brazilian population, and this Brazilian version of the exhibition adds sections on the importance of plant genetics in the nation, including biofuels and engineered crops. All told, the show comes off stronger and more vibrant than ever with the addition of the larger context - the unique living world that Darwin called "a tangled web," - the biodiversity at the very heart of Brazil.
Fig. 4 During overland travel in Brazil, Darwin observed that smaller modern armadillos appeared much like giant fossil relatives. Credit: Hill \& Knowlton

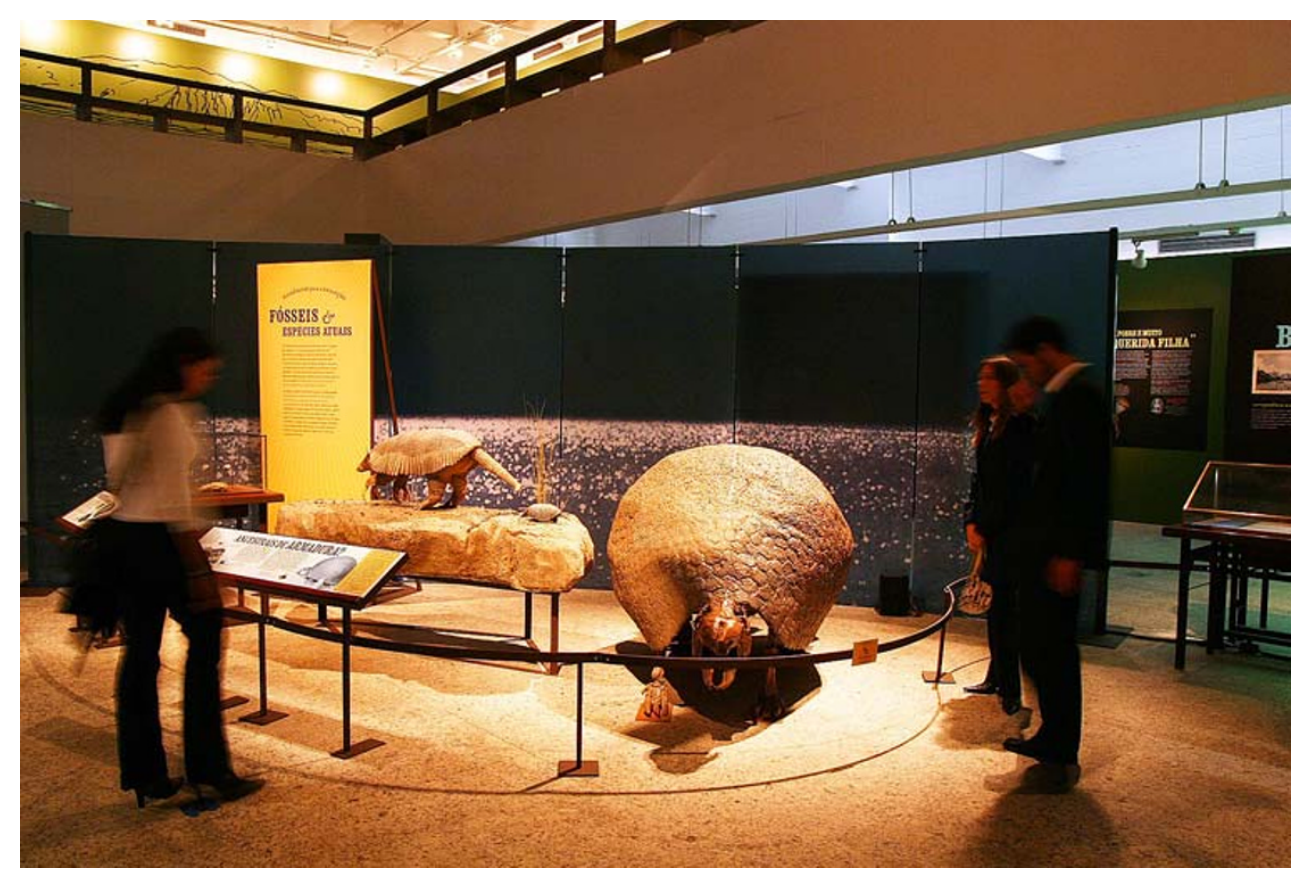


Fig. 5 A sliver of Brazilian rainforest reveals why we should care about conserving biodiversity and connects it to the minute world of DNA. Credit: Hill \& Knowlton
Fig. 6 Common but not commonly seen in town: the $\mathrm{Ge}$ nomic Revolution exhibition gives the students of Saõ Paulo a rare look at life outside the city of 10 million people. Turtle Credit: Alan Draeger, AMNH
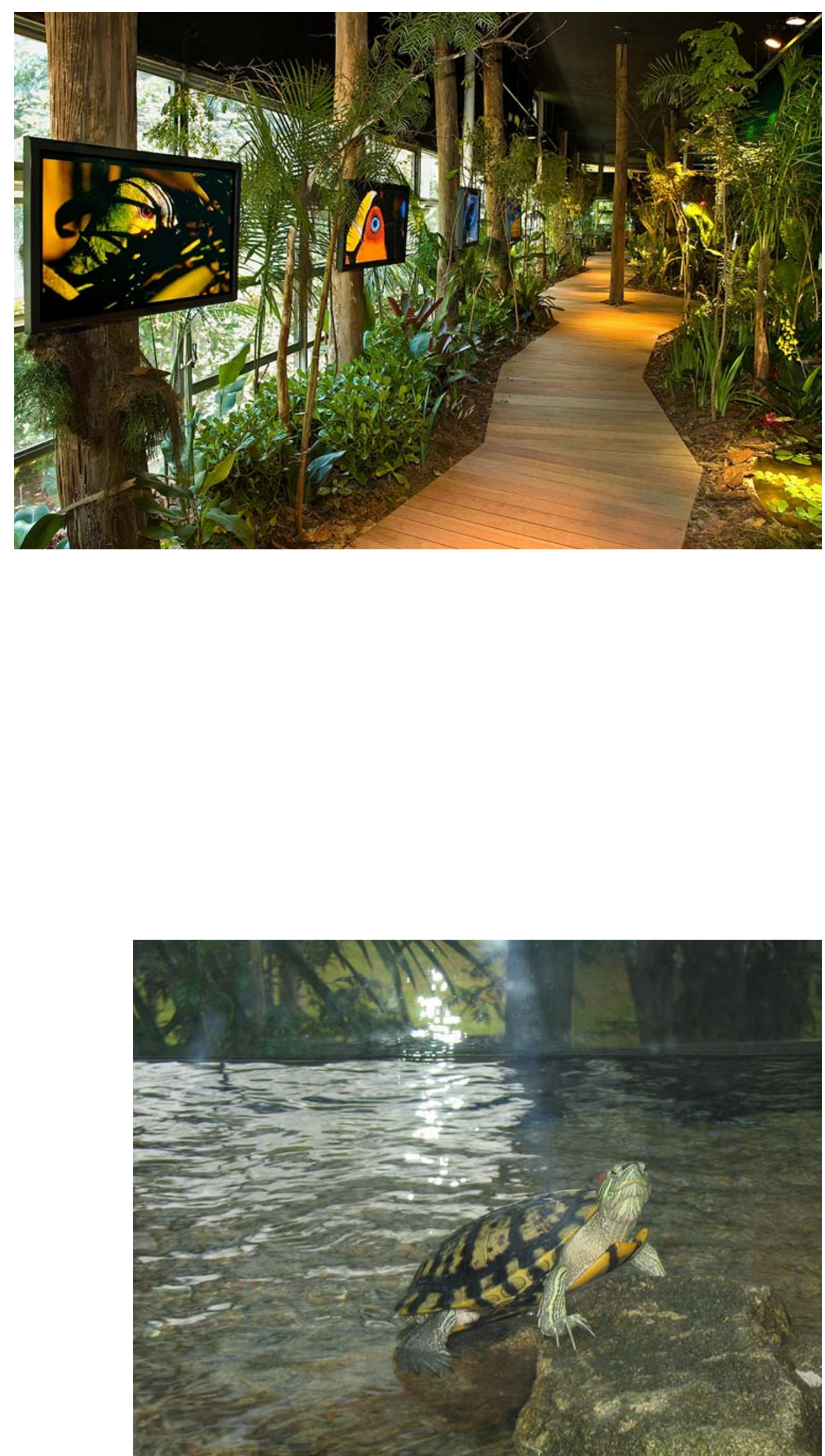
Fig. 7 Common but not commonly seen in town: the Genomic Revolution exhibition gives the students of Saõ Paulo a rare look at life outside the city of 10 million people. Toco toucan Credit: Hill \& Knowlton

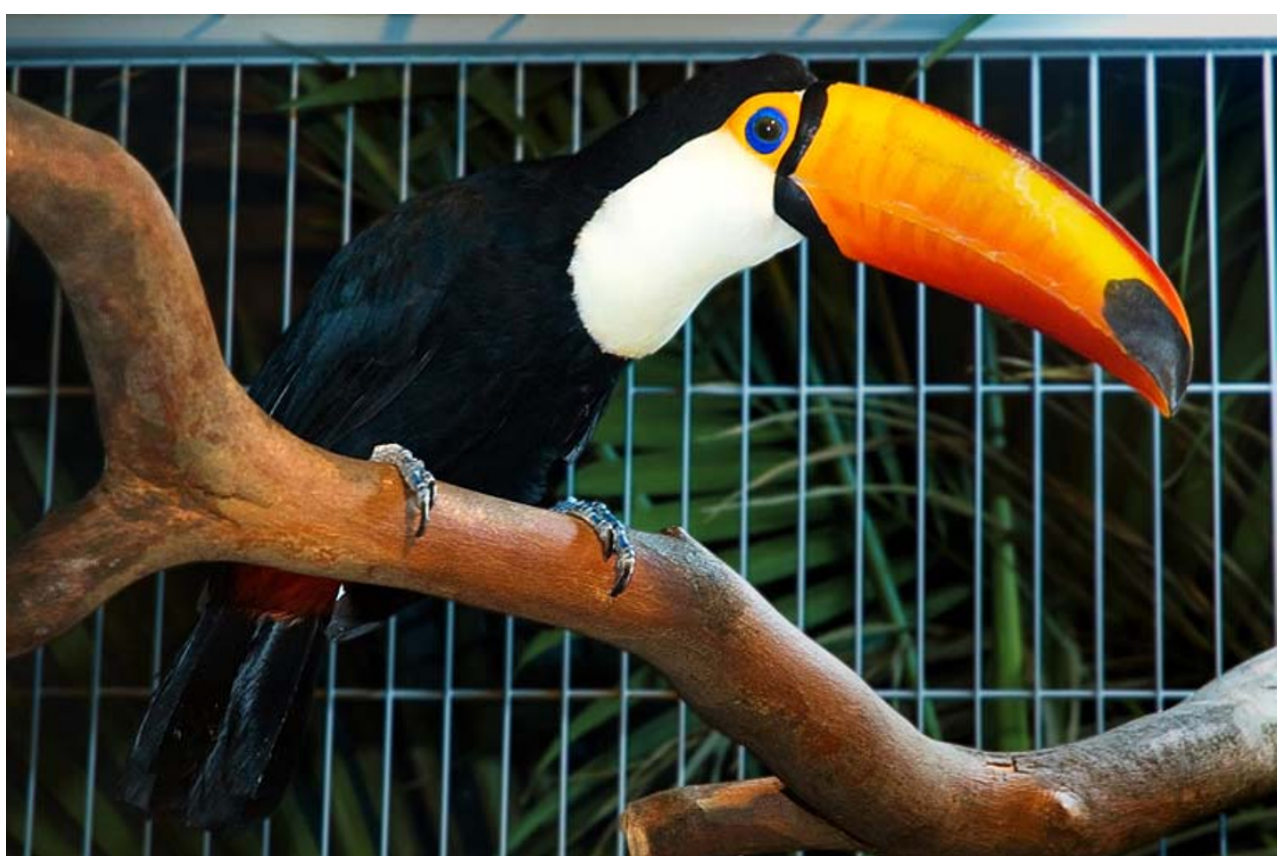

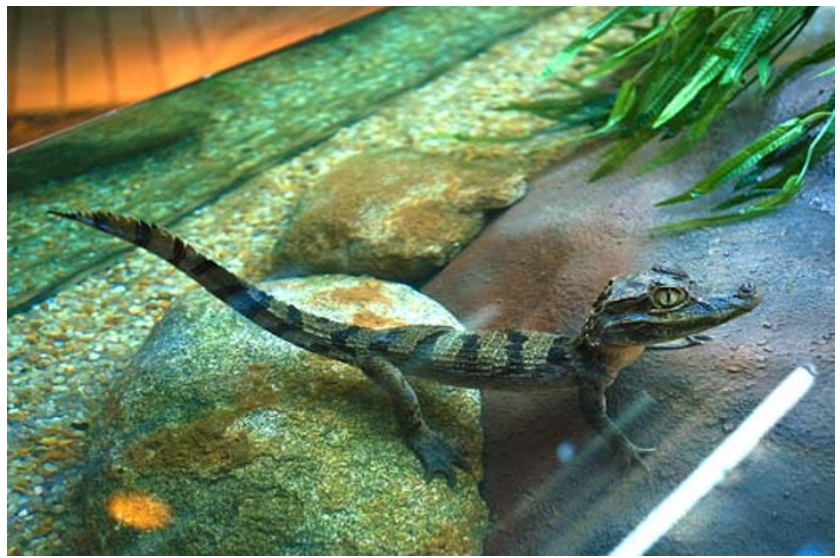

Fig. 8 Common but not commonly seen in town: the Genomic Revolution exhibition gives the students of Saõ Paulo a rare look at life outside the city of 10 million people. Jacare Credit: Hill \& Knowlton

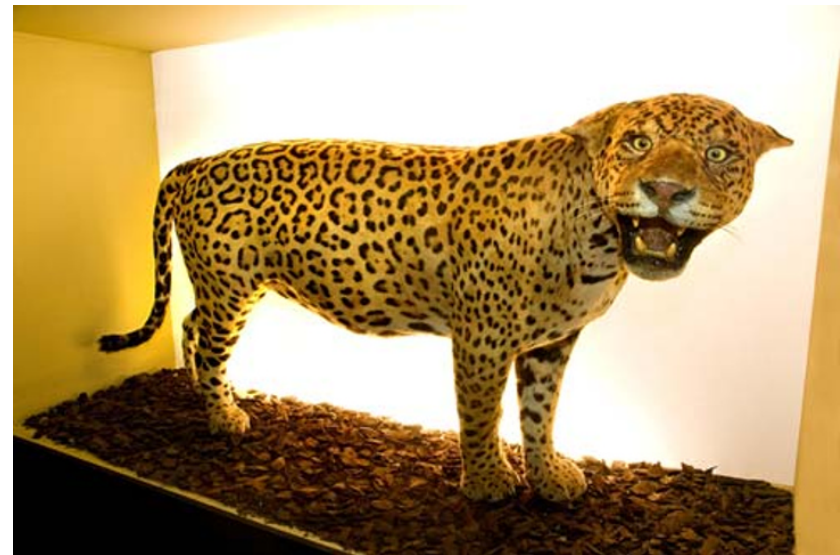

Fig. 9 Brazil declared the jaguar (Panthera onca) an endangered species in 2006 due to human encroachment and loss of habitat. Credit: Hill \& Knowlton 
Fig. 10 single caption: A walkthrough model of a cell gives visitors a look at the organelle, storehouse of DNA. Credit: Hill \& Knowlton

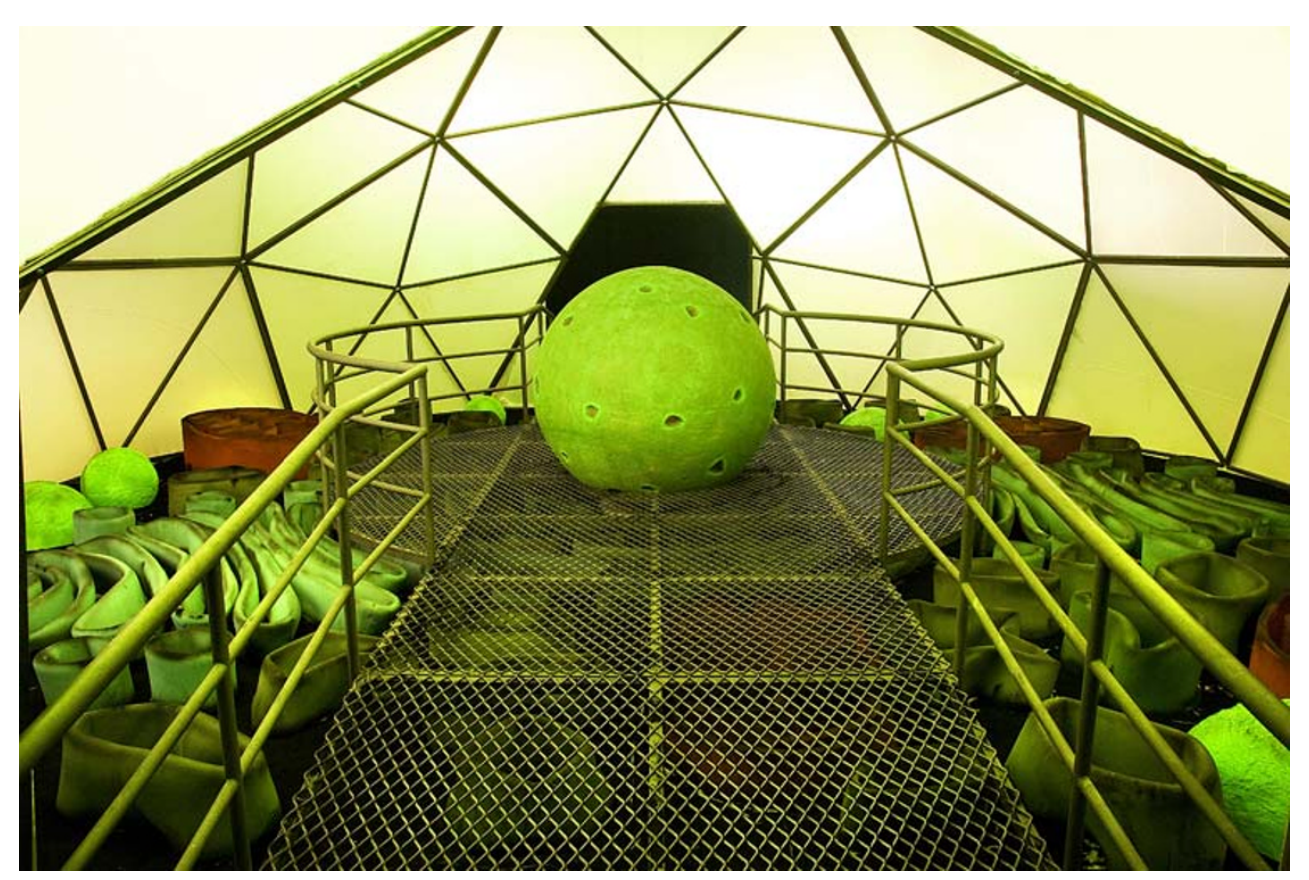

Fig. 11 single caption: A walkthrough model of a cell gives visitors a look at the organelle, storehouse of DNA. Credit: Hill \& Knowlton

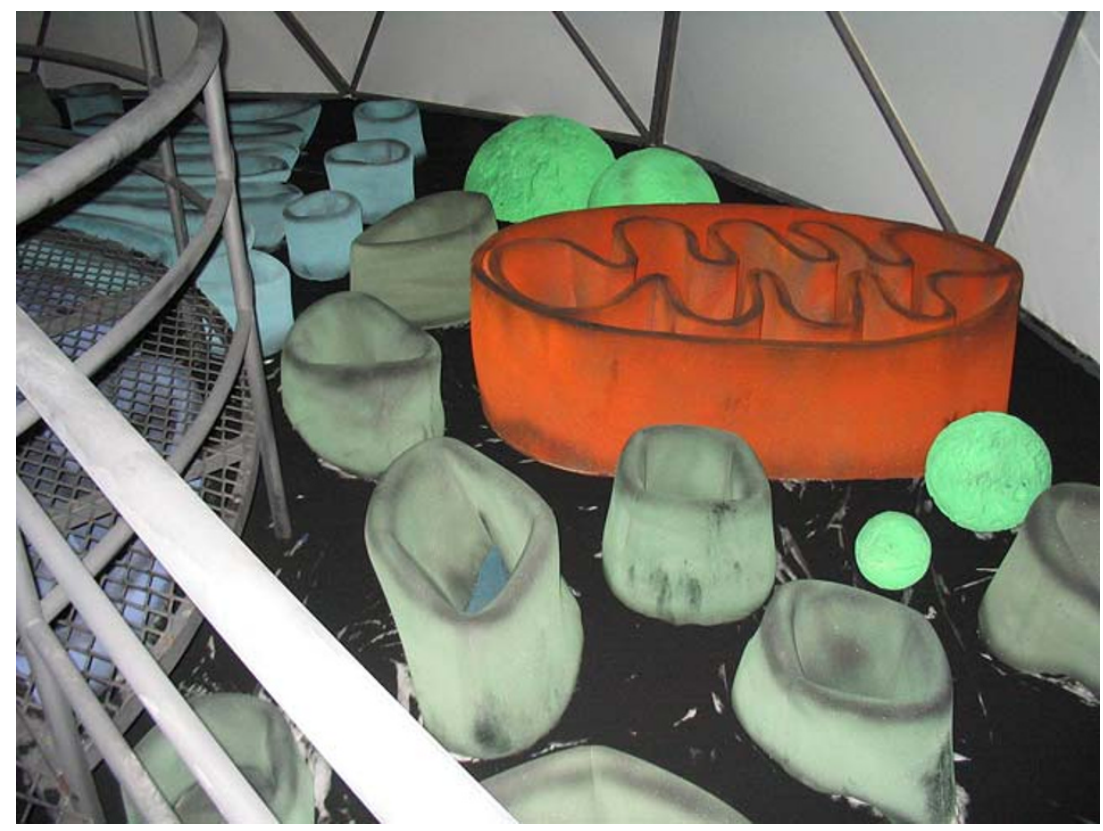


Fig. 12 When Darwin saw the Brazilian Atlantic rainforest for the first time, he wrote back to his family, "the mind is a chaos of delight"

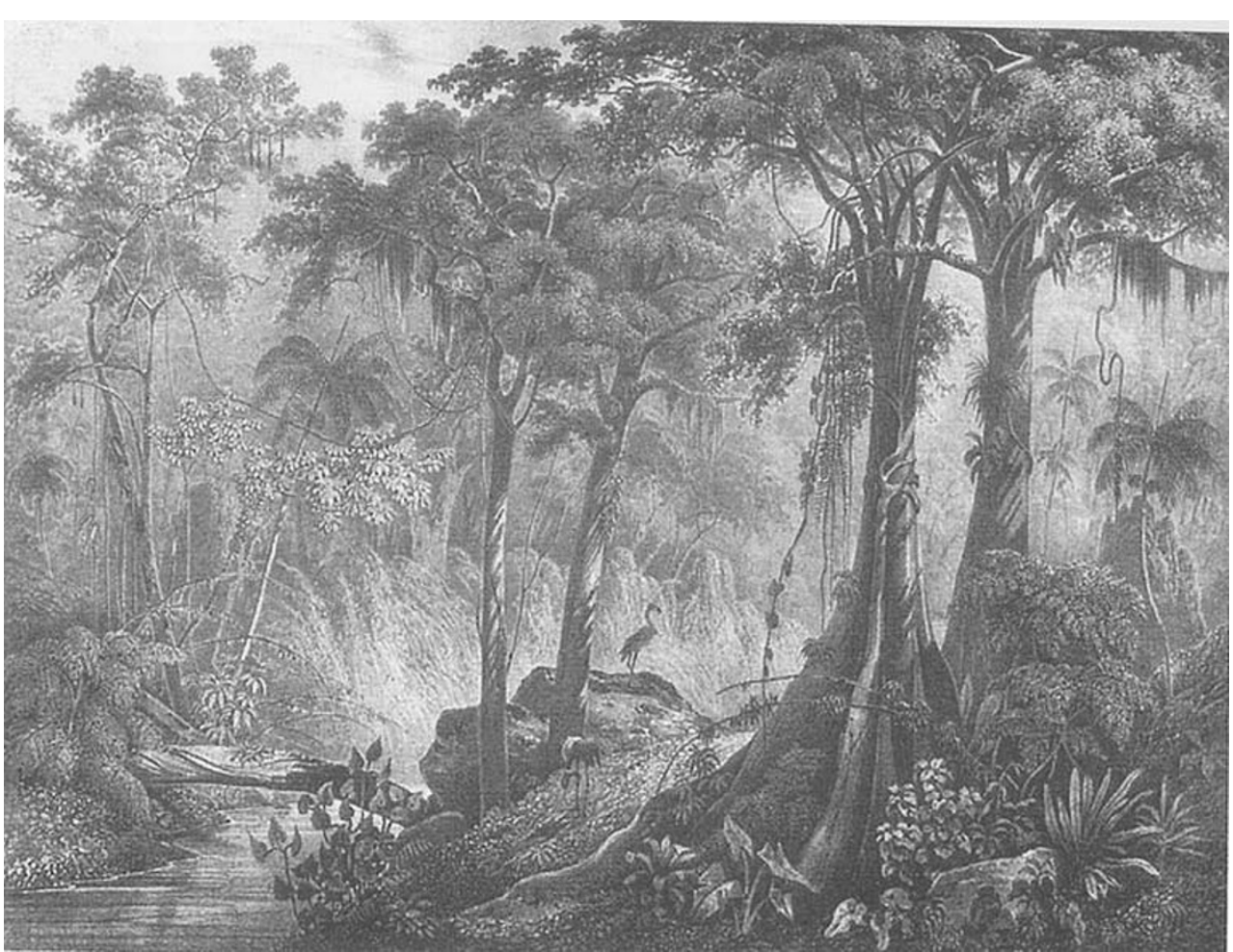

